\title{
Wartime Everydayness: Beyond the Battlefield in China's Second World War
}

\author{
Hans van de Ven
}

Episodically horrific but historically insignificant: this was the consensus judgment of the significance of the Second World War for China well into the 1990s. The real driver of change had been the revolution that had erupted out of village China. The Nationalists came in for harsh criticism: they had contributed little to the defeat of Japan; they largely avoided fighting the Japanese in order to gather up Allied supplies to use them later against the Communists; and they had been an incompetent, dictatorial regime. ${ }^{1}$

Things have changed. Now most historians, including in China, agree that the Nationalists did most of the fighting against the Japanese while the Communists sat out the war in the hills of northwest China. The Nationalists, the argument is, conducted a defence of their country that was surprisingly effective given the state of its economic development. They led an agricultural society to resist invasion by a modern industrialized army, doing so alone for four long years while the Western powers in Asia - the UK, the USA, France, and the Netherlands - stood idly by as Asia burned. ${ }^{2}$ The Nationalist's adoption of a defensive strategy aimed at exhausting the Japanese was not a sign of Nationalist incompetence, but the only rational means for the Nationalists to conduct the war. ${ }^{3}$ Historians now argue that during the Second World War the survival of China as a country and a culture had been at stake and that the transformations that took place then had long-lasting consequences. Few continue to dismiss historically irrelevant.

One benefit of the new scholarship is better knowledge of the course of the war. All those who want to familiarize themselves with China's Second World War can turn to a substantial secondary literature in both Chinese and English. ${ }^{4}$ Gaps remain, of course. The battlefields of north China continue to await serious research. The coverage of the war's last few two years is sparse, even though the period was in reality decisive. In 1944, Japan conducted its largest operation on land during the Second World War in China. Operation Ichigo destroyed much of the remaining

\footnotetext{
${ }^{1}$ Lloyd Eastman, Seeds of Destruction: Nationalist China in War and Revolution (Standford, Stanford University Press, 1984) and Barbara Tuchman, Stilwell and the American Experience in China (New York, Bantam Books, 1972).

${ }^{2}$ Mitter stresses this point in The Struggle for Survival, whose US title is Forgotten Ally.

${ }^{3}$ Hans van de Ven, War and Nationalism in China (London, Routledge,

${ }^{4}$ See for instance, Mark Peattie, Edward Drea, and Hans van de Ven, eds, The Battle for China: Essays on the Military History of the Sino-Japanese War (Stanford, Stanford University Press, 2011); Stephen MacKinnon, Wuhan, 1938: War, Revolution and the Making of Modern China (Berkeley, University of California Press, 2008), Rana Mitter, China's War with Japan, 1937-1945: The Struggle for Survival (London, Penguin, 2014); Diana Lary, The Chinese People at War: Human Suffering and Social Transformation (Cambridge, Cambridge University Press, 2010); Hans van de Ven, War and Nationalism in China: 1925-1945 (London, Routledge, 2003). Peter Harmsen, Shanghai 1937: Stalingrad on the Yangze (Oxford, Casemate, 2013); Yang Tianshi 杨天 石, In Search of the Real Chiang Kaishek: Reading the Chiang Kaishek Diaries (找寻真实的蒋介石：蒋介石日 记解读) (Taiyuan, Shanxi Renmin Chubanshe, 2008) and The Secret Archive of Chiang Kaishek and Chiang Kaishek's True Identity (蒋介石密档与蒋介石真相) (Beijing: Social Sciences and Documents Press, 2002); Zhang Xianwen 张宪文, History of China's War of Resistance (中国抗日战争史) (Nanjing, Nanjing Daxue Chubanshe, 2001), Zhang Xianwen History of the Republic of China (中华民国史) (Nanjing, Nanjing Daxue Chubanshe, 2005); Yang Kuisong 杨奎松, Revolution (革命) (Nanning, Guangxi Renmin Dubanshe, 2012), especially volume 3. The Institute of Modern History of the Chinese Academy of Social Sciences published a special journal, War of Resistance Studies (抗日战争研究), devoted to the topic.
} 
strength of the Nationalists. Fanning out over north China, the Communists exploited the opportunity with skill and speed. The Nationalists never recovered from the damage Ichigo inflicted on their domestic as well as international reputations. Nonetheless, if gaps remain, the basic contours of the history of the war are now clear.

Despite these advances, we still know little about the war beyond the battlefield. The Nanjing Massacre, the chemical warfare experiments of Unit 731, and sexual slavery are well-known, including beyond academic circles. ${ }^{5}$ These were horrific events, but the fighting had other, more mundane, but just as pervasive consequences. In eight years of fighting, hundreds of thousands soldiers battled across the country, tens of millions of refugees fled their homes, and commodity flows of for instance rice, wheat, oil, and salt, all critical to survival, were disrupted repeatedly. Shops closed, banks became bankrupt, and markets shut down. Temples, churches, schools, and universities were occupied, put to new uses, looted, or destroyed. In mobilizing their societies, governments improvised new administrative structures, pioneered new ways of acting as states, and extracted huge sacrifices from their subjects. My interest is in exploring these everyday effects of the war on Chinese society, politics, economy, and culture.

Attention to these aspects offers, I believe, three advantages. First, it allows us to think about the war in other ways than as a series of battles and atrocities, the continuous repetition of which in textbooks, scholarship, and the media has turned them into historical set pieces, if not clichés, used more often than not to sustain current hierarchies of power. Histories of the War of Resistance have stuck to traditional modes of writing military history. This is the war of Chiang Kaishek and Mao Zedong, of Chongqing and Yan'an, of the Battles of Shanghai and Wuhan, of the bombing of Chongqing, and of Allied relations. We learn little about village China in all its complexity and variety or about conditions in small and medium-sized towns with their teahouses, opera theatres, schools, temples, churches, and mosques. Yet, the war had profound consequences at these levels of society.

Second, the effects of the war off the battlefield on popular attitudes, the public mood, and the talk in the street is important for understanding the course of the war. Carl von Clausewitz argued long ago in the aftermath of the Napoleonic war that three factors were decisive in war. The first was rational calculation, that is, the decisions of commanders and politicians as they formulate plans and strategies to realize their aims. The second was chance, namely all the unpredictable events that happens when armies collide: the fog of war. Finally, there was morale not just of the armed forces but also the larger population. The scratch armies of revolutionary France had defeated better-trained German forces because of their revolutionary zeal. Investigating China's

\footnotetext{
${ }^{5}$ There is now a vast literature on the Nanjing Massacre. Iris Chang, The Rape of Nanking: The Forgotten Holocaust of WWII (Harmondsworth, Penguin, 1998) is a controversial classic. See also Tasashi Wakabayashi, The Nanking Atrocity, 1937-38: Complicating the Picture (New York, Berghahn, 2007), Li Feifei, Robert Sabella, et al, eds, Nanking 1937: Memory and Healing (Armonk, M.E. Sharpe, 2002), Yang Daqing, 'Revisionism and the Nanjing Atrocity', Critical Asian Studies, vol 43:4 (2011), 625-48. Zhang Xianwen has compiled a 28 volume collection of relevant documents from archives around the world: Zhang Xianwen, ed, Collection of Historical Documents for the Nanjing Massacre (南京大屠杀史料集) (Nanjing, Jiangsu Renmin Chubanshe, 2006). For research on Unit 731, see: Sheldon Harris, Factories of Death: Japanese Biological Warfare, 1932-45, and the American Cover-Up (London, Routledge, 2002), Hal Gold, ed, Unit 731 Testomony (Boston, Tuttle, 1996); Aoki Fukiko, 731: Unit Seven Three One (Tokyo: Shinchosha, 2005); Unit 731 Criminal Evidence Musem (侵华日军 关东军七三一部队罪证陈列馆), ed, Chemical Warfare Unit 731 of the Kuantong Army of Japan's Invading Forces ( 侵华日军关东军 731 细菌部队). On comfort women, see: George Hicks, The Comfort Women: Japna's Brutal Regime of Enforced Prostitution (New York, Norton, 1997); Maki Kimura, Unfolding the 'Comfort Women's Debates: Modernity, Violence, Women's Voices (Basingstoke, Palgrave Macmillan, 2015), Peipei Qiu et al, eds, Chinese Comfort Women: Testimonies from Imperial Jana's Sex Slaves (New York, Oxford University Press, 2013).
} 
wartime everyday will, I hope, give us a better grasp of the latter aspect of the War of Resistance, the public mood in all its social, regional, and generational complexity. A divided China with weak armies, no industrial base, and indifferent governments with limited capacity resisted powerful Japanese armies for eight long years. We will not be able to explain this if we have a better understanding of general attitudes toward the war.

Third, looking beyond military and political leaders provides an opportunity to investigate personal and intimate responses to these violent times. The great number of diaries and memoirs published in recent years has revealed personal perspectives on the war. In these, individuals are not faceless victims overwhelmed by war's horrors, but persons enmeshed in webs of attachment, endowed with feelings, emotions, and imaginations, and active participant operating in complex social networks. They give us insight in the imaginative responses to the war, the effects on family and generational relations, and in meaningful silences and taboos, so important to sustain social groups under stress. ${ }^{6}$ Investigating these kinds of everydaynesses has only just begun. Not the least advantage of writing about these topics is that its results speak to the concerns of a new post-war generation, less concerned with star generals, major politicians, and big battles, but with identity and memory.

'Wartime everydayness' is, I hope, a usefully concise way of referring to the basket of issues I have outlined above. The term takes account of the fact that no matter how deep the disruption, devastating the damage, and traumatic the turmoil caused by the war, people developed new normals, at least for the duration of the war. The term draws attention to the mundane, the familial, the intimate, and the communal. It draws on the Altaggeschichte developed in Germany. In investigating China's wartime everydayness, though, we do not have to be concerned with the Nazi legacy for obvious reasons nor with locating redeeming acts of resistance especially among the poor and powerfulness, as Altaggeschichte often is. ${ }^{7}$ Instead, I hope that the term offers a way to talk about the war in less politicized ways, with the issues of wartime guilt, collaboration, and collusion and resistance occupying a less prominent place and with our common humanity coming to the fore.

I proceed as follows. I sketch out first some effects of the war on the economy. I then turn to exploring the reading lives two elite Chinese. Disillusionment in Nationalist modernity was the main result for one; the other, in contrast, developed a deep commitment to the healing functions of art, literature, teaching, and the family. I finally explore the wartime popularity of a new historical genre, the general history (通史). As all Chinese studying at wartime universities regardless of their specialization had to take a general history course, general surveys, produced by some of the most prominent historians of the day, tell us how their country's history was presented to young university students, who were often exiles themselves, at a moment of huge national crisis.

\section{The Economic Side}

Two examples, one drawn from a wartime diary and the other from a recent memoir, are good illustrations of what I mean by wartime everydayness. The memoir is from Chi Pang-yuan 齐邦 媛, the daughter of prominent Manchurian exile who grew up during the war. After fleeing from

\footnotetext{
${ }^{6}$ Famous recent examples are Lung Yingtai 龙应台, 1949: Big River, Big Sea (大江大海) (Hong Kong, Tiandi Tushu, 2014), Chi Pangyuan 齐邦媛, Big Flowing River (巨流河) (Taipei, Yuanjian Tianxia, 2014), and tr. John Balcom, Columbia University Press, 2018. Chen Fong Ching 陈方正, ed, Chen Kewen Riji, 1937-52 (陈克文日记) (Taipei, Institute of Modern Chinese History of the Academia Sini a, 2012). The Institute publishes an outstanding series of memoirs of leading historical figures.

${ }^{7}$ For an overview in English of Altaggeschichte, see David Crew, 'Altaggeschichte: A New Social History from Below', Central European History, vol.22:3/4, 394-407.
} 
Nanjing, the Nationalist capital taken by the Japanese in December 1937, Qi first attended secondary school in Chongqing, China's wartime capital, and then studied at Wuhan University, which relocated to Leshan 乐山 in western Sichuan Province after Wuhan fell to the Japanese in October 1938. The diary is from Chen Kewen 陈克文 (Chen Kai-wen in Cantonese), a senior civil servant in the Nationalist Executive Yuan. Chen was from an impoverished family of educators from Guangxi in south China. He was able to make good because of the spread of Western-style modern schools in Republican China, first gaining admission to the provincial middle school in the capital of his province and then to the Teachers University of Canton. Swept up by the May Fourth Movement, he joined the Nationalists, believing that they would transform China into a modern nation. An ally of Wang Jingwei, the Nationalist Number Two and Chiang Kaishek rival who in December 1938 began an illfated effort to forge a settlement with the Japanese, he was never powerful in his own right. Chen Kewen stayed in Chongqing after Wang Jingwei's departure. The Nationalists kept him on at the Executive Yuan, presumbaly as an illustration of Chiang Kaishek's magnanimity toward Wang Jingwei's followers. There was no purge.

In her artfully constructed memoir, Chi Pang-yuan recounts her arduous and often dangerous yearlong journey from Nanjing to Chongqing, describes the appreciation she acquired for the beauty of China's countryside, and waxes lyrically about her teachers, whom she admired as much for their learning as for their dedication to their students. After the war, Chi returned to coastal China. When she arrived in Shanghai, she was unable to adjust to its consumerist lifestyles. She felt 'vulgar' in a 'Chongqing outfit' that consisted of a baggy blue cotton dress and 'round leather shoes with soles made of tyre' ${ }^{8}$ A friend's sister, who refused to be seen publicly together with Pang-yuan in her Chongqing garb, took her clothes shopping. When she put on a dress more in tune with the Shanghai fashion of the day and looked into a shop mirror, she 'saw someone I did not recognize'. ${ }^{9}$ The war changed fashions, not only reflecting wartime scarcities, but also embodying, literally in this case, new identities and new social divisions fashioned in the war. This is a simple but telling example of the effect of the war on one young person's wartime everydayness, materially as well as emotionally.

After the Japanese won the Battle of Shanghai in November 1937 and then forged their way to Nanjing, the Nationalists evacuated government personnel to Wuhan by ship. Chen Kewen was among the evacuees. Rather straitlaced, he was offended by his colleague's singing of popular ditties, their dancing, and their womanizing aboard ship. In Wuhan, he ate for the first time deepfried dough stick (油条) and flat bread (烧饼). Both are popular breakfast foods especially in north China. ${ }^{10}$ Before the war, Chen breakfasted on vegetarian noodles. He was surprised that he liked them and believed that consuming them was patriotic. He noted in his diary, 'Christian General Feng Xuxiang 冯玉祥[regarded as a patriot] is quite right in arguing that flat breads are much better than foreign bread'. ${ }^{11}$ During the war, tens of millions of refugees had to change their diets just like Chen Kewen. This was important in a country where local cuisines are key cultural markers.

Changes in consumption patterns reflected the war's impact on China's economy. A primary concern of the Nationalists was securing the supply of basic life necessities such as food, textiles, and salt. Japan's occupation of the Nationalist heartland caused the Nationalists the loss of their main revenue sources, including taxes on maritime trade, the salt tax, and the consolidated tax on factory products. They also lost access to international markets, including for rice, important because coastal provinces such as Guangdong, Fujian, and Zhejiang were rice-importing areas. At the same

\footnotetext{
${ }^{8}$ Chi, Big Flowing River, 254-5.

${ }^{9}$ Ibid.

${ }^{10}$ Chen, ed, Diary, 173.

11 Ibid.
} 
time, the Nationalists faced the burden of having to supply armies that had swollen to some three million men.

Until 1941, the Nationalists were remarkably effective in meeting this challenge. They did so in part by the simple expedience of withdrawing into regions that were poor but were agricultural productive, including Anhui, Henan, Jiangxi, Hunan, and especially west China's rice-basket, Sichuan. They profited from benign climatic conditions in 1938 and 1939, but just as important were Nationalists campaigns to bring additional agricultural land under cultivation, to settle refugees on vacant or abandoned land, introduce new crop varieties, develop irrigation schemes, and promote high calorie crops such as potatoes, wheat, and peanuts. ${ }^{12}$ The Nationalists followed a policy of placing the financial burden of the war on urban populations and future generations (by printing money) rather than the countryside. Taiwan historian Hou Kunhong 侯坤宏 has shown that these policies were relatively successful until $1941 .{ }^{13}$ After that, the beginning of the Pacific War, which cut China off from all access to international markets, Japanese conquests of agriculturally productive regions, and inflation caused the situation to deteriorate. The outbreak of the Pacific War was a turning point because, as a British intelligence report stated, 'goods reaching Shanghai found their way to Free China by devious means; these supplies will now be cut off'. ${ }^{14}$

A 1942 report of the Ministry of Economic Affairs illustrates the depth of the problems China faced by this time in the War of Resistance. It reviewed the supply of coal, cotton, and edible oils as well as less significant items such as paper, candles, and soap. Cotton, used not only for textiles but also for bedding, was deeply problematic. The report estimated that production, most of which took place in Shaanxi and Henan, yielded 1.8 meters of cotton cloth per person, amounting to one third of requirements. The demand for cotton was elastic up to a point, but only up to a point. The purchase of new clothes could not be postponed indefinitely. The Nationalists considered establishing a cotton monopoly, but decided against this because it was believed that the Nationalist government apparatus was incapable of securing complete control of the cotton harvest and the textile market. An attempt to establish a monopoly would lead to black markets and profiteering. Instead, the Ministry of Economics established a rationing system to supply the army and civil servants. ${ }^{15}$ This complex reality lay behind Chi Pangyuan's Chongqing fashion.

The report stated that the production of coal, used for heating and as a source of energy for industry and railroads, was sufficient in quantity, but that transport difficulties led to scarcity in Sichuan, where the Nationalists had located a new, and much bombed, industrial base. It advocated that the state supply domestic users with inferior quality coal only and that industry should inform the Ministry of their coal requirements, with the state supplying these at state set prices. Cooking oil was critical to the Chinese diet as China did not have a dairy industry and hence the country did not produce butter. The Ministry's Report argued that production fell short of minimum needs by $10 \%$. It recommended measures to increase cultivation of seeds that produced oil and that the state procure half of production to supply urban centres and combat inflation. ${ }^{16}$

The situation for salt, essential to the human diet, was just as fragile. Pre-war China depended on sea salt for $80 \%$ of the country's needs. Following Japan's occupation of coastal regions, unoccupied China came to depend largely on rock salt mined in Sichuan and Yunnan to supply a population grown by tens of millions of refugees. Output fell from 21.3 million kilos to 9.5

\footnotetext{
12 Hans van de Ven, War and Nationalism in China, 1925-1945 (London, RoutledgeCurzon, 2003), 258-63

${ }^{13}$ Hou Kun-hung, 'The Supply and Demand of Grains during the War of Resistance' (抗战时期粮食供求问题研

究), MA dissertation, National Chengchi University, 1988.

14 'The Economic Situation in Free China: The Food Situation in Szechuan', UK National Archives, HS1/48.

${ }^{15}$ Hans van de Ven, War and Nationalism, 282.

${ }^{16}$ Ibid.
} 
million kilos in 1941 and 6.6 million kilos in 1945. Production fluctuated greatly, with some years, such as 1940 and 1943 showing significant upturns. Nonetheless, the overall situation was dire, even though the Nationalists put significant effort in maintaining production, including by introducing new mining techniques and by the organization of purchasing and distribution networks. ${ }^{17}$

The processes outlined above can be summarized as the de-modernization of the economy. The historian and diplomat Jiang Tingfu 蒋廷楉 noted on a trip back to his hometown in Hunan in spring 1940 that rural households had dusted off their spinning looms and oil from tung trees had replaced kerosene for lighting. ${ }^{18}$ Inns had reopened along traditional trade routes. Economic demodernization was not all bad: many of those thrown out of a work as the China coast industrialized were in demand again. According to Jiang, coolies once again found employment, their wages went up, and their bargaining power increased. Many energetic and enterprising persons who had travelled to coastal cities and towns to work, write, study, or play returned to their families back in village China, bringing their wealth, skills, and connections with them.

The war changed China's trade patterns also because the importation of warfighting materials became a priority. China lacked a significant arms industry of its own. Before the war, textiles, kerosene, matches, tobacco, and light industrial products made up the bulk of China's imports. Up to October 1941, the Soviets provided 1500 aircraft, 160 tanks, 1800 pieces of artillery, 1300 vehicles, and 100,000 rifles. ${ }^{19}$ The conclusion of a neutrality agreement between the Soviets and the Japanese in April 1941 halted Soviet exports of materiel to China, but the USA then took over. Its Lend Lease programme supplied weapons, ammunition, kerosene, industrial machinery, bank notes, and many other things, with most of it arriving in the last year of the war.

Because supply lines into China were long and cumbersome, supply dumps grew up along the way. After relations between China and especially the Americans deteriorated after 1943 about a range of issues, including global military strategy and arrangements for the reinvasion of Burma, critics of the Nationalists used these rhetorically to paint the Nationalists as incompetent, unpatriotic, and corrupt hoarders. ${ }^{20}$ Stockpiles became a symbolic short hand to paint the Nationalists in a negative light and to veil the US and UK decision to give priority to the European theatre. Trade is never just a material thing. It comes with serious symbolic baggage.

Wartime trade fuelled the adoption of numerical managerial techniques. The Second World War boosted the rise of such ways of thinking and acting around the world. Bureaucracies developed and devoured registers, tables, statistics, graphs, and figures in the effort to ensure that the required number of troops were at a designated place at the right time with the right equipment and food in order to carry out a specific military task. In 1932 the Nationalists established the National Defence Planning Council (国防设计委员会) to research China's economic, cultural, social, and political conditions and develop plans to build the industries, mines, railroads, airports, and bureaucracies necessary to fight a modern war. The National Resources Commission took over its functions during the war. The archives of both are full of long inventories, detailed planning documents, and equally detailed quarterly, half-yearly, and annual reviews. They were suggestive of a level of government control that must often have fallen short of reality.

\footnotetext{
${ }^{17}$ Zhang Lijie 张立杰, 'Institutional Change in the Salt Administration in Nationalist Area in the Later War of Resistance' (抗战后期国统区的盐政改制), War of Resistance Research ( 抗日战争研), vol.3 (2004), 141 - 62. 18 Jiang Tingfu 蒋廷䊇, Memoirs of Jiang Tingfu (蒋廷馛回忆录) (Changsha, Yuelu Shushe, 2003), Huiyilu, 217- 225.

${ }^{19}$ Yang Kuisong 杨奎松, A Middle Zone Revolution (中间地带的革命) (Taiyuan, Shanxi Renmin Chubanshe, 2010), 479.

${ }^{20}$ Judd Kinzley, 'Assessing the Stockpile: Material Aspects of Allied Wartime Aid to China', paper presented at 'China in a Global WWII' Summer Institute, Cambridge, 3-15 July 2017.
} 
If that was a high-level consequence of modernist approaches to governance, a more down to earth one resulted from Nationalist wartime refugee resettlement programmes. Micah Muscolino traced the Nationalist use of refugees fleeing the deluge resulting from the breaking of the Yellow River dikes to the Huanglongshan area of Shaanxi province. The main aim of the Nationalists was to improve the food supply. But, it also organized the 50,000 or so displaced persons who made it to the region to foster nationalism, eradicate what it saw as backward religious practices, and use the region, which had become wasteland after the late Qing rebellions, to ward off the Japanese as well as the Communists. ${ }^{21}$ Interestingly, the measures it promoted, including the irrigation schemes it implemented, enabled the area to survive better the disastrous Great Leap Forward policies of the Communists in the late $1950 \mathrm{s.}^{22}$

\section{Worlds of Reading: Chen Kewen and Qi Bangyuan}

If China de-modernized during the War of Resistance economically, the same was not true culturally. Chen Kewen was an avaricious reader during with a cosmopolitan taste. Among the books and plays Chen read during these years were Ba Jin's 巴金 The Dead Sun (死去的太阳, 1931); Gorky's Summer Folk (1904), My Childhood (1914), and My Travel Companion; a number of works by Lao She 老舍, including Divorce (离婚, 1943); Harold Laski's The American Presidency (1940); Lin Yutang 林语堂, Love and Thorns (爱与刺, 1941); H.G. Wells, The Shape of Things to Come (1933); Wendell Wilkie, One World (1943); Zhang Junmai 张君励, The Way to Establish a Nation (立国之道); Cao Yu, Sunrise (日出，1936) and Peking Man (北京人, 1940); Feng Youlan's 冯友兰 New NeoConfucianism (新理学, 1939), Xia Yan's 夏衍 translation of Tolstoy's Resurrection (1899); James Jeans, The New Background of Science (1933); Liang Shuming, A Theory for Rural Reconstruction (乡 村建设理论, 1931); an abbreviation of Darwin's The Descent of Men (1871); Erich Maria Remarque, All Quiet on the Western Front (1927); and Emil Zola, L'Assommoir (1877). Chen also enjoyed telling stories to his son, Chen Fong-ching. He drew on Chinese traditional fiction, especially The Three Kingdoms and The Robbers of the Marshes, to keep Fong-ching entertained. ${ }^{23}$

Chen held the historian F.J.C. Hearnsnaw and the novelist H.G. Wells in especially high regard. He had translated Hearnshaw's Outline Sketch of the Political History of Europe in Hong Kong in 1930. The Outline Sketch argued that rational liberal elites formed the real makers of European history, leading ignorant, poor, and exploited masses to overthrow aristocratic and religious privilege. ${ }^{24}$ Wells's The Shape of Things to Come made the same argument in fictional form. A history of the future, Shape is cast as a history textbook published in 2106. It narrates the history of the world from 1933 until then as the story of nationalism, economic malaise, religion, and war nearly destroying humankind. A government of air controllers brings salvation by abolishing the nation-state, outlawing religion, and enforcing good citizenship. The appeal of Hearnshaw and Wells to Chen is unsurprising. Chen Kewen had drunk deeply from the well of New Culture Movement rationalism, with its critique of Chinese traditions, its adulation of 'Mr Science' and 'Mr Democracy',

\footnotetext{
${ }^{21}$ Micah Muscolino, 'Refugees, Land Reclamation, and Militarized Landscapes in Wartime China: Huanglongshan, Shaanxi, 1937 - 45', Journal of Asian Studies vol. 69 (2010), 453 - 78.

22 Muscolino, 'Water Conversation projects in Shaanxi and Gansu', paper presented at Summer Institute 'China in a Global WWII', Cambridge, 11 July 2017.

${ }^{23}$ Chen, 'Introduction', in Chen, ed, Diary, XV.

${ }^{24}$ F.J.C. Hearnshaw, An Outline Sketch of the Political History of Europe in the $19^{\text {th }}$ Century (London, Macmillan, 1919), 13, 170. https://archive.org/details/cu31924024835617
} 
and its privileging of the role of educated elites. ${ }^{25} \mathrm{He}$ saw his own role as civil servant as helping to realize modern liberalism in China.

Chen Kewen's war proved an education in disillusion. In Nanjing, he had been optimistic about the future and marvelled at the progress that China was making, a progress he saw inscribed in the wide boulevards, the lighting, the new office buildings, and the modern residences that sprouted up across the city. After the war began, disappointments piled up rapidly. Chen was infuriated when he learned in December 1937 that Hunan and Hubei provincial work reports were largely fictional. ${ }^{26} \mathrm{He}$ was appalled when his fellow civil servants took to the dance floor on the ship that took them from Nanjing to Wuhan, singing 'Sister, I love You' as hundreds of thousands died on the battlefield and refugees struggled to get out of the way of danger. ${ }^{27} \mathrm{He}$ was furious when provincial governments fled rather than stayed at their posts to help their fellow citizens. ${ }^{28}$ Finance Minister Kong Xiangxi came in for repeated criticism because of his corruption. Chen quoted with approval a colleague in the Ministry who had said that 'just one Kong family is enough to sink our state'. ${ }^{29}$ In 1944, he agreed with the diagnosis, made by British journalist and Communist sympathizer Stuart Gelder, that 'the lower levels of society in China are selfish embezzlers and the higher levels are incompetent and cowardly'. ${ }^{30}$ 'In truth', according to Chen Kewen, 'China's deficiencies have long been like this. If we must wait for a foreigner from a friendly nation to point them out to improve things, it's too late' ${ }^{31}$ A sense of duty convinced Chen to stick with the Nationalists. He called it a day, though, at the end of the Civil War. He declined to join the Nationalists in Taiwan. He spent his remaining days in Hong Kong, teaching and writing.

Chi Pang-yuan's response to the war was the opposite. Her reading of Chinese, Russian, French, and English literature allowed her to relativize the traumas she had to experience and uncover different, more hopeful, realities. Literature inspired in her a respect for culture and beauty and gave her faith in human decency, tenderness, and compassion. It showed that there had been periods of terrible destruction in the past, but that these had ended without destroying all that was good in humans.

Chi Pangyuan attended the Nankai Middle School in the Shapingba district of Chongqing, coming under the spell of Chinese literature teacher Meng Zhisun 孟志荪, who introduced her to The Book of Odes (诗经), The Song of the South (楚辞), The Nineteen Classical Poems (古诗十九首), Tang poetry, famous essay compositions, and modern literature. Teacher Meng had his students memorize many poems. 'Day and night I recited poetry. When I now look back quietly, in these two years I memorized most of the greatest work in the history of Chinese literature'.$^{32}$ Like many intelligent but reticent young students, Chi spent her vacations reading, including the great Chinese novels Dream of the Red Chamber, the modernist poetry of He Qifang 何其芳 and Bian Zhilin 市之 琳，Russian literature, including Gorky, Tolstoy, and Turgenev, and Andre Gide's Symphonie Pastorale.

\footnotetext{
25 John Fitzgerald, Awakening China: Politics, Culture, and Class in the Nationalist Revolution (Stanford, Stanford University Press, 1996).

${ }^{26}$ Chen, ed, Diary, $144-45$.

27 Ibid, $145-146$.

28 Ibid, 156.

${ }^{29}$ Ibid, 170.

30 lbid, 852.

31 Ibid, 852.

${ }^{32}$ Chi, River, 115.
} 
From Nankai Middle School Chi moved on to Wuhan University, which had relocated to Leshan Mountain, 250 kilometres east of Chongqing, far away from Japanese bombing. The site was well chosen. Leshan, near sacred Emei Mountain, was the place where China's greatest poet, Du Fu, had sought refuge and time to compose poetry in a similar period of destruction back in the eighth century. Contrary to her father's advice, Chi had first chosen philosophy as her subject, but Dean Zhu Guangqian 朱光潜 convinced her to switch to English literature. Zhu was famous, having taught at Peking University and edited Literature Magazine (文学杂志). Zhu's Twelve Letters to Youth (给青年 的十二封信) and On Beauty (谈美) were 'must reads' among high school students in the Republican Period. Chi regarded the opportunity to study with him as an enormous privilege. ${ }^{33}$

As his textbook Zhu Guangqian used The Golden Treasury of English Songs and Lyrics, of which half a million copies circulated around the world by the time of the Second World War. In it British Romantic poetry had pride of place. Their work - elegiac, sonorous, rich in imagery, but also accessible - spoke to the losses and shocks most students faced. During her journey from Nanjing to Chongqing, Chi had lost a sister, her mother had been near death, and Japanese aircraft were a constant threat. One Japanese air raid hit the Chi family home; her father shielded her ill mother sick in bed from the rain with an umbrella. A bomb had destroyed the roof of their home. Pang-yuan was also constantly worried about Zhang Dafei, a Manchurian orphan and a close friend of the family for whom she developed romantic feelings. Zhang was a pilot in the Chinese air force.

Wordsworth's The Lucy Poems enthralled Chi: 'their profound but natural and common feelings have rarely been expressed better until today'. ${ }^{34}$ In the third poem, 'I Travelled Among Unknown Men', Wordsworth declared that he would never leave England again because its green fields were the last places that Lucy saw. 'To the me of that time, when my love for my country trumped everything else, this was a most beautiful and powerful poem about patriotic feeling'. ${ }^{35}$ Zhu also had Chi read Percy Shelley's 'Ozymandis', a sonnet about the decay of empires as well as of literary fame. Zhu usually read poetry out in a calm voice, but this time 'he waved his hands with great animation. Reading the sentences of the poem, he taught us to see with "our mind's eye...This was the first time that I really saw the imagery of Western poetry, and I never forgot it'. When she read Shelley's 'The Indian Serenade', in which the poet, overcome with emotion, falls to the ground, saying 'I Die! I Faint! I Fall!,' Chi found that it expressed 'the sorrow I had no way of expressing' ${ }^{36} \mathrm{Chi}$ Pang-yuan's wartime reading opened up a world in which personal relations, feeling, learning, humane values, and beauty rather than war, revolution, and violence stood central. It gave her the words, metaphors, and symbols with which to express her feelings, and discover some of which she had been barely aware, or not at all.

A theme that runs through Chi's memoir is the contrast between her world, that of study and literature, and the battlefield, where Zhang Dafei was a pilot. The message was that China did not only sent part of its youth to fight the Japanese on the battlefield, but also made sure to educate

\footnotetext{
${ }^{33}$ For an astute characterization of Zhu as a Socratic intellectual, see Chen Jinling, 'The Socratic Tradition in Modern China', in David Derwei Wang, A New Literary History of Modern China (Cambridge, Mass, Harvard University Press, 2017), 533-39. See also Li Zehou 李泽厚, ‘On Aesthetic Perception, Beauty and Art (Research Outline. And also on Zhu Guangqian's Idealism (论美感，美和艺术（研究提纲） - 兼论朱光潜的唯心主义) in Philosophical Research (哲学研究), vol.5 (1956), 52 - 60 .

${ }^{34} \mathrm{Chi}$, River, 183.

$35 \mathrm{Ibid}, 183$.

${ }^{36}$ Chi, River, 192.
} 
another part of that youth to sustain China's cultural and civilizational traditions. Unsurprisingly, that is exactly what Chi would do with the rest of her life.

I have mapped out the worlds of reading of Chi Pangyuan and Chen Kewen not because I believe them to be representative. However, I have examined them to illustrate that memoirs and diaries reveal to us worlds of thinking and feeling about which documents drawn from archives are silent. The Chi Pangyuan and Chen Kewen cases illustrate that mining them provides us glimpses into the divergent experiences of and responses to the War of Resistance of two articulate members of the Chinese public. If nothing else, they show that there was rather more to China's will to resist the Japanese than an uncomplicated nationalism.

\section{'Times of Trouble': Civilizational Sensibilities}

The historian's job is rarely easy, but spare a thought for China's historians reading, writing, and lecturing during the Second World War. Many, though by no means all, joined the exodus of writers, artists, musicians, and scientists from the cities in coastal China, where they had held major positions at prestigious universities such as Peking, Qinghua, Fudan, and Nankai Universities, all established in the late Qing and early Republican periods. After they had been driven from their homes and while bombs rained down on them, they faced the question 'now what?'.

To complicate the task, if Japan had driven China out of China physically, China's historians had burned China's house of history to the ground in the aftermath of the 1911 Revolution. Already in the late Qing, reformist scholars produced books and articles, as sophisticated as they were electrifying, arguing that the dynasty-endorsed versions of the Confucian Classics were falsifications, thus challenging the constitutional foundation of Qing rule. They still held firm to the belief in the existence of a Confucian golden age, one that could be accessed by the recovery through careful philology of the true Classics, from which lessons could be drawn for good governance and for the good life. The 'Doubters of Antiquity' (疑古) in the 1920s rejected the whole notion of a classical age. Another school, shaped by the USA's New Historians, called for the application of strict rational logic to reconstruct China's history, not to restore belief in its value, but to free China from its sticky tentacles. ${ }^{37}$ This was history as a corrosive, useful to clean the rust of tradition from Chinese culture, but with no other value. ${ }^{38}$

There was some good news. Chinese archaeologists, conducting digs between 1929 and 1937 at Anyang in Henan Province, recovered copper vessels, burial chambers, earthenware, foundations, and oracle bones. They demonstrated that the Shang Dynasty $(1766-1122$ BC) had in fact been real. Their work confirmed the reliability of traditional histories whose veracity scholars had called into doubt. ${ }^{39}$ In the process, they added more than half a millennium to China's history, giving China a civilization of astounding antiquity. If that restored pride, the essential problem remained. Following decades of historical scepticism, a century of painful defeats by Western

\footnotetext{
${ }^{37}$ Qian Mu 钱穆, Survey of Our National History: Revised Version (国史大纲: 修订本) (Commercial Press, http://www.yabook.org, no page numbers), introduction.

${ }^{38}$ For an astute survey of historical debates in the Republican period, see Lawrence Schneider, Ku Chieh-kang and China's New History: Nationaism and the Quest for Alternative Traditions (Berkeley, University of California Press, 1971). See also Tu Cheng-sheng (杜正胜), The New Path for Historical Studies (新史学之路) (Taipei, Sanmin, 2004).

${ }^{39}$ Chen Yung-fa 陈永发, Pursuing Excellence: Eighty Years of the Academia Sinica (追求卓越：中央研究院八 十年) (Taipei, Academia Sinica, 2008), I, 29 - 31; Li Chi, Anyang (Folkestone, Dawson, 1977). Tu Cheng-sheng, New Path, $174-215$.
} 
powers, and Japan's occupation of the country's heartland, did China's history offer anything valuable or should it just be put on display in a museum?

The war breathed new life into history. Many, although not all, leading historians refused to stay in occupied China. They taught at exile universities such as Associated University in Kunming, made up Nankai, Peking, and Qinghua Universities. There they gave lectures and wrote articles and books. Because all students regardless of their specialization had to take a course in Chinese history, general history survey course were well attended. That created a need for history surveys. No less than twenty appeared during the first six years of the war. ${ }^{40}$

Qian Mu 钱穆, Lei Haizong 雷海宗, and Fan Wenlan 范文澜 were three prominent authors of radically divergent history textbooks. Their histories were scholarly, in the sense that sound historical scholarship and deep reading informed them. But they also wrote to give their readers reasons to persist with resistance to Japan and inspire them with a belief in the existence of better futures. Despite a few fragments in a number of memoirs, we cannot know how they responded to their lectures. But we can imagine them, sitting in improvised lecture rooms on overcrowded campuses, away from their families, listening to the star teachers, trying to get their bearings in the situation in which they now found themselves, and formulating answers to the problems they and China faced.

Let me first turn to Lei Haizong. A Chicago Ph.D., Lei was a terrific lecturer. One of his students, Ho Ping-ti, a major post-war historian of China in his own right, recalled his excitement at hearing Lei holding forth on Western and Chinese history without notes. ${ }^{41}$ Lei drew on the civilizational approach made famous by Oswald Spengler and Arnold Toynbee to rescue Chinese history from Eurocentric historiographical dicta and restore agency and vitality to Chinese history. Spengler and Toynbee insisted that not nations but civilizations were the proper subject of history. For Toynbee, the fate of a civilization depended on the ability of its elites to develop creative solutions to external challenges. He diagnosed his own time as a Time of Trouble: the industrial revolution and globalization had made European culture dominant, but European civilization was declining because Western elites were failing to provide answers to the problems of their time, including domestic popular grievances in Europe and anti-colonial movements elsewhere. ${ }^{42}$

Toynbee is largely forgotten now. Few historians would still adhere to his organicist understanding of civilizations. The religious connotations of his later writing and his belief in history's moral purpose is alien to our post-modern minds. Many, though not all, have rejected the usefulness of the concept of civilization for historical research. ${ }^{43}$ However, Toynbee was a star historian in the

\footnotetext{
${ }^{40} \mathrm{Li}$ Ping 李萍, 'A Preliminary Assessment of the Reasons for and Achievements of Two High Tides in Writing Chinese History Surveys' (中国通史写作的两次高超及其原因试析), Anhui Historical Studies (安徽史学 ), vol.3 (2000), $93-96$.

${ }^{41}$ Ho Ping-ti 何炳棣, 'My Recollections of Lei Haizong' ( 雷海宗先师回忆), in Nankai University History Institute (南开大学历史学院), ed., Lei Haizong and Twentieth Century Chinese Historical Studies: Essays in Commemoration of the $100^{\text {th }}$ Anniversary of Lei Haizong's Birth (雷海宗与二十世纪中国史学：雷海宗先生 百年诞辰纪念文集) (Beijing, Zhonghua Shuju, 2005), $42-47$.

42 Michael Lang, 'Globalization and Global History in Toynbee', Journal of World History, vol.22:4 (2011), 759 774. For a biography of Toynbee, see William McNeill, Arnold Toynbee: A Life (New York, Oxford University Press, 1989).

${ }^{43}$ See Samuel Huntington, The Clash of Civilizations and the Remaking of World Order (London, Simon and Schuster, 1997); William McNeill, The Rise of the West: A History of the Human Community (Chicago, Chicago University Press, revised edition, 1991): and Niall Ferguson, Civilization: The West and the Rest (London,
} 
1930s and 1940s, especially after he published the first three volumes of his A Study of History. Jiang Tingfu, the historian mentioned earlier, was proud to have met him during a visit to London and called him 'a second Lord Acton'. 'His intelligence truly is a glory for the United Kingdom and the twentieth century'. ${ }^{44}$ For historians like Lei, Toynbee's work, with its rejection of European uniqueness and insistence that no civilization had ever be stagnant, was liberating. It allowed them to rescue Chinese history from charges of stagnation and backwardness and give it meaning for the China of their day.

Lei is most famous for his 1940 Chinese Culture and Chinese Soldiers (中国文化与中国的兵), made up of five essays from before the outbreak of war and two later ones. They were broad-brush treatises, written in a punchy style. They eschewed textual glosses and philological notes derived from 'rotten slips of bamboo and fragments of documents'. ${ }^{45}$ Before the outbreak of war, Lei reconstructed Chinese history as having gone through two civilizational cycles. In the first, lasting until the fourth century AD, a pure 'Chinese' 华夏 civilization had emerged, matured, and then declined in the Yellow River valley. The invasion by northern peoples in the third century AD had nearly terminated China's civilization, but Chinese forces had defeated the invaders at the Battle of Fei River in 383 AD, preventing them from taking over the Lower Yangzi Region and south China. That victory paved the way for a second cycle in Chinese civilization, one that drew on the vitality of southern elites and evolved in response to the stimulus provided by the arrival of Indian Buddhism. Because they had not been defeated completely, its bearers could claim a connection with the first cycle. ${ }^{46}$

Before 1937, Lei was pessimistic about China's future. The inability to defend China against the Manchus and Western imperialism, the stultification of learning caused by the examination system, the self-indulgence of its scholar-bureaucrats who preferred philological hair-splitting to serious thought and disdained the military: all these were signs of fatal decline. The outbreak of war with Japan, though, prompted Lei to blunt his pessimism. In 'National Reconstruction: Anticipating a Third Cycle', one of the final two essays in Chinese Culture, Lei argued that China's refusal to surrender to Japan suggested China's continuing vitality. China, so he argued, just might be at the beginning of an unprecedented third civilizational cycle. He called on his compatriots to grasp this 'unprecedented privilege'. ${ }^{47}$

It is a moot point whether Lei spoke from genuine conviction. Together with historians Lin Tongji 林同济 and Chen Quan 陈铨, he became one of the movers behind the journal The Warring States (战国策). It advocated the creation of a war culture involving all of Chinese society under strong central leadership to lead China at this time of wars of annihilation. The group argued that force was everything, and that justice or virtue counted for little in the contemporary world. The journal triggered a huge polemic. The Masses, a communist periodical, subjected the group to

Penguin, 2012). On the possible return of civilization as a concept, see Krishnan Kumar, 'The Return of Civilization - and of Arnold Toynbee', Comparative Studies in Society and History, vol.56:4 (2014), 815 - 843,

44 Jiang Tingfu 蒋廷栯, Memoirs of Jiang Tingfu (蒋廷栊回忆录) (Changsha, Yuelu Shushe, 2003), 173 - 75.

45 Isreal, Lianda, 148.

${ }^{46}$ Lei Haizong 雷海宗, Chinese Culture and China's Soldiers (中国文化与中国的兵) (Hong Kong, Longmen Shudian, 1968), ... FB 87.152

47 See Ho Ping-ti (何炳棣), 'The Forgotten “Lei Haizong Era” - Remember Master Lei Haizong' (被忽视的“雷海 宗年代” - 忆雷海宗师', http://www.guoxue.com/master/leihaizong/leihaizong.htm: Hans van de Ven, China at War (London, Profile, 2017), 109. 
severe criticism for three years, including accusing it fascism. ${ }^{48} \mathrm{Xu}$ Jilin, a contemporary public intellectual and historian of Chinese thought, has sprung to the defence of this group. He has argued that Lin Tongji was at heart a Daoist, but believed that, in contrast to Europeans, Chinese lacked a transcendental commitment to their countries. He wrote to stimulate its emergence through his writing, not to reveal his innermost convictions. ${ }^{49}$

Like Lei, Qian Mu wrote his history to provide his fellow citizens with better reasons to fight the Japanese. Qian Mu was a one-off. Unlike most other leading Republican historians, he did not have a university education and had not spend long periods outside China. He gained his learning in the traditional way, first at home and then in private schools. He began his career as a local schoolteacher, until he published an break-though monograph that landed him a position at Yenching University in Peking. Qian argued for a critical but empathetic understanding of the past. He is often pigeon-holed as a traditional neo-Confucian, but that does not do him justice. He agreed that fundamental changes were necessary to meet the challenges of modernity that China faced. But they had to be built on a thorough understanding of China's past and be consistent with China's traditions..$^{50}$

Qian Mu published his famous Survey of Our National History (国史大纲) in June 1940. It developed out of a course on Chinese history that he had begun teaching in 1933 at Peking University. Qian wrote it in haste, fearing that he might be the last Chinese to write a history of China before the country ceased to exist. He holed himself up in a Buddhist monastery in the mountains, so that he and his notebooks were safe from bombing, coming down to give his lectures at Associated University on Thursdays, Fridays, and Saturdays. ${ }^{51}$

Qian Mu was fond of drawing stark broad-brush juxtapositions between European and Chinese history. 'China's history is a poem; the Western one is drama', he famously declared. ${ }^{52}$ Qian argued that European civilization had made its great advances in periods of violent upheaval. China, on the other hand, had progressed in periods of peace in a gradual and evolutionary way. If Socrates drank a beaker of poison and Christ was crucified, Confucius had died peacefully. Rome had been a centralized and militarized empire of conquest. When Rome collapsed, Europe disintegrated into a Dark Age from which it recovered only when new centralized states emerged. Not so in China. The military had lost its hold soon after unification under the Qin Dynasty, change came from the bottom rather than the top, and China had absorbed its neighbours culturally and economically in peaceful processes.

Qian agreed with Lei Haizong that a periodization derived from the European experience was of little use to comprehend Chinese history. He rebelled against the idea that history was the story of the emergence of democracy out of dictatorship and capitalism out of feudalism. That story line did not work for China, where power had dispersed throughout Chinese society much earlier

\footnotetext{
${ }^{48}$ Pu Weidong 蒲卫东, 'The Critique of the Warring States Faction in the Weekly “The Masses", 1942-45' (1942-1945 年间《群众》周刊对战国策派的批判), 2017 Wuhan University M.Phil. dissertation.

${ }^{49}$ Xu Jilin 许纪霖, 'From the Realm of the State to the Realm of Nature: The Thought Trajectory of a Chinese Intellectual' (从国的境界到自然境界：一个中国知识分子的心路历程), in Xu Jilin, How Did Enlightenment Return from the Dead (启蒙如何起死回生) (Beijing, Peking University Press, 2011). See also Xu Jilin, 'An Intense but Rich Spirit: Research on the Thought of Lin Tongji' (紧张而丰富的心灵：林同济思想研究), in Historical Research (历史研究), vol.4 (2003), 100-110, 190-191.

50 Ibid.

51 Ibid.

52 Ibid.
} 
than in Europe. In China, land had been alienable from early on and hence feudalism had not been a significant phenomenon. Similarly, religion had mattered only in the a-typical Period of Division (220 - 589 AD), when Buddhism flourished.

Where Qian Mu differed from Lei Haizong was that he did not believe that China required a powerful state. China was not a society kept together by force or law, or by a powerful leader, but by a sense of 'emotional connectedness' (感情), kept alive and refreshed in the daily practices of all Chinese. Qian did not think that China lacked a transcendental commitment beyond narrow family interests, as the Warring States School argued. ${ }^{53}$ He believed in the essential vitality and strength of Chinese local society. China's future dependent on that rather than grand initiatives from a strong central government. The anthropologist Fei Xiaotong 费孝通， who had studied with Malinowski at the LSE, articulated a similar position in Peasant Life in China.$^{54}$ Jiang Tingfu shared this view. Jiang toured the countryside in 1940 to re- familiarise himself with local conditions after a period abroad. He encountered many promising local initiatives to improve agriculture, strengthen public health provision, and increase the effectiveness of local government. A central government attempt to implement a five-year compulsory education system for all Chinese made no sense to him. China's soldiers were underfed and lacked the arms they needed to fight the Japanese. A compulsory education system was a nice dream, but China could simply not afford it at this time. ${ }^{55}$

The most influential general history would prove to be not that of Qian Mu, Lei Haizong, or any other Chongqing or Kunming historian, but rather Fan Wenlan's Concise General History of China 中国通史简编, published in 1943 in Communist Yan'an. The Communists could not leave unchallenged Qian's and Lei's arguments that China had followed a different historical trajectory than European societies. Marxist dogma demands that all societies travel through the historical stages of primitive communism, slave society, feudalism, and capitalism before they arrive at communism. In Communist historiographies, class conflict determined by economic relations is the main driver of change. They could certainly not accept Qian Mu's arguments about China having progressed only in periods of peace and that rebellions had been historically unproductive. They needed a history that justified revolution.

Mao Zedong asked Fan Wenlan to put his talents to writing a Communist general history after Fan arrived in Yan'an, dragging along tens of boxes of books. Fan was an astute choice, in two ways. First, he had the credentials, having become famous as a pre-eminent historian with deep knowledge of China's historical and literary traditions before the war. Second, he was not an orthodox Marxist-Leninist and that suited Mao. In a series of pamphlets in first few years of the War of Resistance, Mao had argued for adjusting Marxism-Leninism to Chinese conditions. He had advanced the proposal that China now needed a 'new democratic revolution' rather than a bourgeois revolution, as orthodox Marxists argued. In the communist scheme of things, the Nationalists represented the bourgeoisie. Mao argued that the course of the revolution in China had to follow a different trajectory because imperialism had weakened and divided China's bourgeoisie: they would never overthrow capitalism. Even if China remained in a semi-colonial and semi-feudal stage, rather than a capitalist one, Communists therefore had to take charge of the revolution.

\footnotetext{
${ }^{53}$ Tu Cheng-sheng, 'Qian Mu and Twentieth Century Historiography of Chinese Ancient History' (钱穆与二十 世纪中国古代史学) in Tu, New Path, 229-30.

${ }^{54}$ Fei Xiaotong, Peasant Life in China: A Field Study of Country Life in the Yangtze Valley (London, Routledge, 1939).

55 Jiang Tingfu, Memoirs, $217 f f$.
} 
Unsurprisingly, Fan's Concise History, the first two volumes of which appeared in 1943 and the last one of which saw daylight in 1946, made the case for Mao.

In putting the histories of China written by Qian Mu, Lei Haizong, and Fan Wenlan into dialogue, my aim has been to show that the wartime period was by no means a historical wasteland. The battle of the textbooks was only one of the many cultural debates that made the War of Resistance an intellectually exciting and transformative period. In 1938, the literary historian Liang Shiqiu triggered a furore when he attacked 'resistance stock essays' (抗战八股), called for writings about other subjects, and maintained that a country as weak as China should be careful not to overstate its case. Mao's attacks on May Fourth Literature, his insistence that literature serve revolution, and that Chinese artists should utilize traditional Chinese cultural formats provoked widespread reaction. When the Nationalist Minister of Education gave an award to a play by Warring States Faction author Chen Quan, in which a Nationalist spy is the main protagonist, there was an outcry. ${ }^{56}$ When in 1944 Guo Moruo - author, poet, and historian - published a historical essay about the collapse of the Ming Dynasty and the victory of the Manchus, an essay that amounted to a fierce denunciation of the Nationalists and a prediction of a Communist victory, a storm broke loose in the media that took months to die down. To develop a full understanding of the wartime everyday, it is necessary to recover and analyse these wartime culture wars.

Fan Wenlan won because the Communists imposed a historical orthodoxy. Like Lei Haizong and unlike Qian Mu, many of Republican China' most eminent histories would stay in mainland China after 1949 and would pay a heavy price for declining to fall into line. History ceased to have much vitality, with the past this time not dismissed as 'backward' and hence antagonistic to modernization, as the Doubters had done, but as 'feudal'. Many of their writings, though, were republished when history was allowed to return in the 1990s. They would not have the last word, but their work is once again part of historical debate.

\section{Conclusion}

This article has outlined a few aspects of China's wartime everydayness. I have described the economic de-modernization that resulted from ruptures in flows of food grains, cotton, salt, and coal, stressing that it had positive consequences in the early years of the war for those who had been left behind by the urbanization, industrialization, and commercialization of the pre-war economy. The economic effects of wartime economic disruption would prove long-lasting. Rationing in China, introduced in the war, ended only in the 1990s after Deng Xiaoping's economic reforms increased economic productivity. Economic change reverberated culturally: wartime fashions expressed not just economic scarcity but also shaped new identities.

I have used a diary, a memoir, and three history surveys to sketch out the reading worlds of one young student and an older civil servant and to examine three attempts at producing a new national narrative for China. My hope has been to paint in this way some aspects of the intellectual milieu of wartime China, including the ideas that elites debated and the mood in which these debates took place. In the absence of the mass observation project of British scholars, in which some 500 volunteer observers maintained diaries, or US-style public opinion polls, we have no better way to gauge the evolution of China's public mood, even if we need many more than just the two

\footnotetext{
${ }^{56}$ Study Society for the History of China's War of Resistance against Japan (中国抗日战争史学会), Culture and Education during the War of Resistance ( 抗战时期的文化与教育) (Beijing, Beijing Chubanshe, 1995), 122 125.
} 
examples I have provided to develop a more representative picture. The press is not a good guide for such an enterprise: it was censored during the war and highly politicized in any case.

I am well aware that I have only scratched the surface of China's wartime everydayness. I have not touched on religion, despite its obvious significance in constituting the wartime everyday. Few historians have touched on the subject, although Xue Yu has examined Buddhist patriotic mobilization, including 'sangha rescue teams' that ministered to the wounded and bereaved. ${ }^{57}$ There is no doubt that the war effected religion profoundly. Many religious buildings suffered damage as refugees, students, and soldiers occupied temples, churches, and mosques. Monks, priests, ministers, and imams undoubtedly joined the throngs of refugees. Religious organizations were important in providing charity, in conducting rituals for the dead, and aiding refugees. As Xue suggests, the war witnessed a reconciliation of sorts between the Nationalists, who had been dogmatically and fiercely secularist before the war, and religious leaders, communities, and institutions: both sides needed each other. That reconciliation would have long-term consequences for religious life in Taiwan and initially in the PRC too, although the purges of the 1950s and the Cultural Revolution ended it. Religion is an important topic precisely because it gives insight, even if only indirectly, in the wartime everydayness of the large number of Chinese who had little education and could not read or write. ${ }^{58}$

I have also barely touched on the effects of the war on public life. The Nationalists intensified their weekly commemorations of Sun Yatsen. On 3 December 1941, just before Pearl Harbor, Chiang Kaishek presided over a ritual in honour of Genghis Khan, thus turning China's historically most powerful invader into a hero of resistance against Japanese aggression, a move inspired by the necessity to compete with the Japanese for the support of Mongol communities. The Nationalists turned the death on the battlefield of General Zhang Zizhong in May 1940 into a huge public spectacle, with his body solemnly carried to Chongqing along roads lined with mourners. Welcomed by Nationalist grandees, the remains of General Zhang, who had initially hesitated to join the Nationalist cause, were placed in a temporary resting place in a temple near the city until such time that his hometown was recovered. ${ }^{59}$ China's ultimate war hero, Yue Fei, gained a new prominence in local operas, film, radio, puppet shows, drama, and the press. Traveling drama troupes toured the country to whip up anti-Japanese sentiment by performing plays such as Sorrow for the Fall of the Ming while Mulan Joins the Army was a huge cinematic success. ${ }^{60}$ If heroic resistance was the main theme, subplots dealt with betrayal, corruption, and cowardice. Yet another topic that deserves investigation is wartime radio. The Nationalists made use of this medium to broadcast speeches, patriotic plays, Peking opera, and spoken drama, and distribute news. ${ }^{61}$ There are, then a vast number of topics to pursue.

I hope to have made clear that there was much more to China's Second World War than just defeating Japan or the Nationalist-Communist rivalry. Moving beyond the battlefield and away from the principal wartime political and military players and places opens up new ways of seeing China's Second World War, not as a victim of Japanese aggression or a largely ignored ally, but as a period in which China's everyday changed economically, socially, and culturally. That in turn allows for the making of new comparisons not just with Europe but also with other regions of the world. If China's

\footnotetext{
${ }^{57}$ Xue Yu, Buddhism, War, and Nationalism: Chinese Monks in the Struggle against Japanese Aggression, 1931 - 1945 (New York, Routledge, 2005).

${ }^{58}$ I am grateful to my colleague, Dr Adam Chau, for his remarks about wartime religion in our conversations.

${ }^{59}$ Arthur Waldron, 'China's New Remembering in WWII: The Case of Zhang Zizhong', Modern Asian Studies, 30:4 (1996), 953-54.

${ }^{60}$ Hung Chang-tai, War and Popular Culture: Resistance in Modern China, 1937 - 45 (Berkeley, University of California Press, 1995), $51-92$.

${ }^{61}$ My Ph.D. student William Moriarty is writing a Ph.D. dissertation about this topic.
} 
historians found a new voice in the Second World War and moved away from Western-centric versions of history, in which the Weberian themes of modernization and state-making stood central, similar developments took place elsewhere. Only a globally aware understanding of the Second World War will be able to do justice to this reality. 